\title{
LEGITIMACY OF THE RESTORATIVE JUSTICE PRINCIPLE IN THE CONTEXT OF CRIMINAL LAW ENFORCEMENT
}

\begin{abstract}
Sukardi*
* Doctoral graduate, Faculty of Law, Universitas Hasanuddin, Makassar, Indonesia and an Indonesian Police officer at the Regional Police Headquarter Makassar, South Sulawesi
\end{abstract}

\section{Article Info}

Received : 16 June 2014 | Received in revised form : 7 August 2014 | Accepted : 29 August 2014

Corresponding author's e-mail : sukardi.s3unhas@gmail.com

\begin{abstract}
This research reviews the essence of the restorative justice principle as an approach in the settlement of criminal cases, and it aims to provide an overview of the construction of the restorative justice principle in criminal law enforcement. The outcomes of the research indicate that the restorative justice principle has been subject to frequent study in its understanding as an alternative criminal case settlement method, by way of positioning outside the criminal judiciary system. As it turns out in practice, however, it has certain weaknesses, particularly in view of the accountability and legitimacy aspects of its establishment. Therefore, there is a need for a scientific investigation process for the purpose of determining the status of parties involved in a case, as well as for positioning the case concerned. Based on such view, the restorative justice principle appears to be the ideal approach to be applied in the criminal judiciary system.
\end{abstract}

Keywords: Restorative justice, mediation, criminal judiciary system

\begin{abstract}
Abstrak
Penelitian ini mengkaji esensi dari prinsip keadilan restoratif sebagai pendekatan dalam penyelesaian kasus pidana, dan bertujuan untuk memberikan gambaran tentang pembangunan prinsip keadilan restoratif dalam penegakan hukum pidana. Hasil penelitian menunjukkan bahwa prinsip keadilan restoratif telah digunakan di berbagai pembelajaran dalam pemahaman sebagai metode penyelesaian kasus pidana alternatif, dengan cara posisi di luar sistem peradilan pidana. Ternyata dalam prakteknya, bagaimanapun, memiliki kelemahan tertentu, terutama mengingat aspek akuntabilitas dan legitimasi pendiriannya. Oleh karena itu, ada kebutuhan untuk proses penyelidikan ilmiah untuk tujuan menentukan status pihak yang terlibat dalam sebuah kasus, serta untuk posisi kasus yang bersangkutan. Berdasarkan pandangan tersebut, prinsip keadilan restoratif tampaknya merupakan pendekatan yang ideal untuk diterapkan dalam sistem peradilan pidana.
\end{abstract}

Kata kunci: Keadilan Restoratif, mediasi, sistem peradilan pidana

\section{Introduction}

Criminal law enforcement is one of the existing means for achieving the purpose of law. According to Gustav Radbruch ${ }^{1}$ who has introduced the "ide des recht" theory, there are

\footnotetext{
${ }^{1}$ Gustav Radbruch is a German philosopher who introduces his theory, "ide das recht" where there are three ideal purposes of law, namely: justice, utility and certainty. Gustav Radbruch states "rechct ist wille zur gerechtigkeit" (law is for the sake of justice. Jeremy Bentham in his monumental work "Introduction to the Principles of Morals and Legislation" (1789). Bentham defines it as that property in any object, whereby it tends to produce pleasure, good, or happiness, or to prevent the happening of mischief, pain, or evil, as well as unhappiness to the party whose interest is considered. Utilitarianism assumes that in principle,
} 
three identified purposes of law, namely: justice, utility and legal certainty. The process of criminal law enforcement in the context of achieving the purposes of law is construed within the criminal judiciary system. The criminal judiciary system as the driving force behind criminal law enforcement is expected to be able to materialize the sense of justice of the community, legal certainty as well as utility for the benefit of mankind.

The concept of restitution or compensation to victims is a concept known in the conventional criminal judiciary process, whilst restoration has a broader meaning. Restoration includes restoration of the relationship between the victim and the offender concerned. Such restoration of relationship may be based on mutual agreement between the victim and the offender. The victim may express the loss he/she suffered, while the offender is granted an opportunity to compensate for the same through the mechanism of compensation, reconciliation, community service, or other agreements. ${ }^{2}$

The concept of law enforcement under the Indonesian Criminal Code (KUHP) adopts two mechanisms of criminal law process, namely criminal act which is a normal offence and that which is a complaint offence. ${ }^{3}$ Complaint offence is a criminal act the report of which can be revoked at any time by the complainant, or in respect of which the state, represented by the Police and the prosecutor, has no authority to take the legal proceedings unless it is reported to the competent authorities. On the other hand, normal offence is a form of criminal act which cannot be revoked by the reporting party or complainant at any time, because the Prosecutor has the discretion to prosecute. In the course of criminal law enforcement process development it has become evident that in fact reports of cases which constitute normal offences are frequently being revoked with the investigation being called off by investigators or public prosecutors, based on the consideration that an amicable settlement has been reached between the victim (reporting party) and the suspect, for humanitarian considerations, or for public interest considerations.

The law enforcement phenomena occurring in Indonesia during the last decade illustrate the law enforcement process which has caused controversy, polemics, certain forms of opposition, protests or harsh criticisms from various circles. The opinions from various parties who disagree with such legal process are often based on the assumption that they hurt the community's sense of law, the community's sense of legal justice who actually no longer find the formal legal process through the criminal judiciary system acceptable. For example, the various current cases which have attracted public attention such as: the case of Nenek (Grandma) Minah, aged 55 years old, who stole 3 (three) pieces of cacao beans and was detained for 3

the purpose of law is merely to create utility or happiness for the community. Achmad Ali, 2008, Menguak Tabir Hukum, Ghalia Indonesia, Bogor, page: 67 . The Writer views that justice, utility, and certainty are not the purposes of law; instead, they are instruments to achieve the purpose of law itself. The purpose of law is supposed to be in line with the purpose of human life, which is not only to create peace in the world, but also the salvation of human itself in the afterlife. Law is the concept of balance in human life, with the purpose of materializing salvation for human both in this world and in the afterlife.

2 Jecky Tengens, Tuesday, July 19, 2011, Pendekatan Restorative Justice dalam Sistem Pidana Indonesia, Internet Website: http://hukumonline.com/berita/ baca/lt4e25360a422c2/ pendekatan-restorativejustice-dalam-sistem-pidana-indonesia, accessed on September 25, 2011.

${ }^{3}$ In the elucidation of Article 72 of Indonesian Criminal Code, it was explained that "in principle, if a criminal case occurs, the government, being represented by the police, public prosecutor's office and the judicial body, without any demand from those affected by the crime, shall immediately take actions to conduct examination, prosecution and impose punishments on those who are guilty. However, out of those criminal cases, there are several types; almost all of them are crimes, which can only be prosecuted upon the report (request) from those affected by the crime. These kinds of criminal case are usually called: complaint offences. See Soesilo, R., 1995, kitab Undang-Undang Hukum Pidana (KUHP) along with its complete comments, Article by Article, Cet. 1, Politeia : Bogor, page: 86-87. 
(three) months. ${ }^{4}$ Many circles view the abovementioned actual cases in Indonesia as a concrete example indicating that the criminal formal system tends to be repressive, disregarding the interests of the victim and the offender. This has been frequently causing reactions, controversies and has brought the law enforcement apparatus under the spotlight from various viewpoints and based on various arguments. Some parties are of the view that the law enforcement apparatus have been trapped into normative legal thinking, and that the law conveys a cruel and frightening impression to the community. Furthermore, the expression hurting the community's sense of justice has emerged in such cases. Althought it is yet to be clarified as to which exactly is the community whose sense of justice has been hurt, or which concept of justice is used as parameter in measuring the performance of the law enforcement apparatus and the justice aspect of the community.

The writer holds that the viewpoint used in assessing the abovementioned various cases has been the philosophy of criminalization approach, hence the orientation of criminal proceeding has been focused on the offender's punishment. The consideration underlying such view is the proposition that a theft committed is a minor one since it is disproportionate to the costs the State needs to incur for prosecuting the case. However, being a formal offence, the act of stealing is not assessed based on the consequences of the act committed nor the amount of loss it has caused, but rather, on the fact that the act of stealing is an act which violates various existing norms.

Criminal law enforcement phenomena currently taking place quite clearly indicate that the criminal judiciary system is no longer able to implement its function as the State's representative, representing the victim's interest to prosecute the offender who has harmed the victim. The criminal judiciary system is supposed to be able to fulfill the victim's sense of justice by imposing criminal liability in the form of criminal sanction against the offender. Seen from the criminalization viewpoint, the criminal judiciary system is considered to have failed in creating deterrent effect for perpetrators of criminal acts; in fact, State Detention Houses (RUTAN) and Correctional Institutions ( $L A P A S$ ) are no longer effective solutions to the convicts' reintegration and resocialization process; rather, there has been a shift in the function of correctional institutions whereby they are becoming academy of crime, a place where convicts "improve" their skills in committing criminal acts. ${ }^{5}$

In Eva's preliminary research for her dissertation involving 250 randomly selected people consisting of both offenders and victims of criminal acts, conducted in February 2006 in Jakarta, Bogor and Tangerang, she reached the conclusion that $62 \%$ of the informants chose not to bring the case to the prosecution level (the case stopped at the level of Police), $82 \%$ stated that amicable settlement endeavours were the preferred

\footnotetext{
${ }^{4}$ Nenek Minah, aged 55 years old, Resident of Darmakradenan Village, Ajibarang Sub-District, Banyumas Regency, accused of stealing 3 pieces of cacao beans from where she worked at PT. Rumpun Sari Antan 4 in Darmakradenan village, not far from her house, who was then taken into a legal proceeding at Purwokerto District Court, Central Java with a criminal sentence of imprisonment for one month and fifteen days on a condition that the punishment did not have to be served by the defendant. Previously, nenek Minah had served 3 months of house arrest. The case of nenek Minah drew the attention of various parties, particularly journalists, Non-Government Organizations, and law observers. Various highlights, criticisms up to the forming of opinions from particular parties view that there is a decline in the credibility of law enforcers, namely the police and the public prosecutor's office. See Saladin Ayyubi/Global/fit, Thursday, November 19, 2009, Hakim Menitikkan Air Mata Baca Putusan Nenek Pencuri 3 Biji Buah Coklat, NewsNusantara, Internet Website: http://news.okezone.com/read/2009/11/20/340/277729/340/hakimmenitikkan-air-mata-baca-putusan-nenek-pencuri-3-biji-buah-coklat, accessed on September 25, 2011.

${ }^{5}$ Ibid.
} 
way of settlement of problems arising from a criminal act, whilst such endeavours for amicable settlement do not always have to be in the form of compensation, but mostly through direct apology. Furthermore, $43 \%$ of the initiatives for amicable settlement came from relatives, $35 \%$ from the apparatus, and the remaining, around $22 \%$ from friends or the opponent. Eva concludes that the community contributes significantly towards the poor implementation of the criminal judiciary system in the initial stage of the process, and that the alternative settlement of criminal cases outside the criminal judiciary process is actually the community's preferred way of settlement, bearing in mind the complicated and lengthy bureaucracy they have to face if they bring their case into the criminal judiciary system, the difficulties encountered in substantiation, as well as the cost and benefit considerations of the parties, both the victim and the offender, which have also been among other considerations. ${ }^{6}$

Another issue which has raised concern on the part of OC Kaligis is the "Miscarriage Of Justice" in the Indonesian criminal judiciary system, as described in his Professorial Inauguration Speech on November 8, 2008 at Universitas Negeri Manado titled: "Miscarriage Of Justice Dalam Sistem Peradilan Pidana: Perlunya Pendekatan Keadilan Restoratif." [Unofficial translation: Miscarriage of Justice In the Criminal Judiciary System: The Need for Restorative Justice Approach"]. Miscarriage Of Justice ${ }^{7}$ is a serious issue in the Indonesian criminal judiciary system. The issue of miscarriage of justice is of the same importance as human rights. ${ }^{8}$ The issue of Miscarriage Of Justice has been one of the issues contributing to the decline in the level of the people's confidence in the performance of the criminal judiciary system.

OC Kaligis ${ }^{9}$ explains that in developed countries, among others the United States, the United Kingdom, Canada, Australia, the issue of miscarriage of justicem8bnvm,mgvh $h n j m, 8 h u 87 v c 7$ is discussed both from the legal as well as the political and social perspectives related to the process of the criminal judiciary system. Independent institutions continuously advocate and struggle for justice for the victims of miscarriage ofjustice. Based on the data released by Forejustice, up to date, 2,539 people have been recorded as victims of miscarriage of justice and various cases of miscarriage of justice have been occurring in 70 countries worldwide. Furthermore, OC Kaligis explains that all those victims of miscarriage of justice in 70 countries consist of: 182 people who were executed; 498 people who were imposed with the death penalty; 543 people who were imposed with lifetime sentence; 1,124 people who were sentenced to an

${ }^{6}$ Eva Achjani Sulfa, June 2009, Keadilan Restoratif Di Indonesia (Studi tentang Kemungkinan Penerapan Pendekatan Keadilan Restoratif Dalam Praktek Penegakan Hukum Pidana), Doctoral Dissertation in the Field of Law, Faculty of Law at Universitas Indonesia, page : 7

7 The word "miscarriage" literally means the failure to achieve a desirable goal. The adding of the word "justice" behind the word "miscarriage" means failure to achieve the goal of justice enforcement. Clive Walker \& Keir Starmer, Ed, in Otto Cornelis Kaligis, 2008, Miscarriage Of Justice Dalam Sistem Peradilan Pidana: Perlunya Pendekatan Keadilan Restoratif, Professorial Inauguration Speech, Universitas Negeri Manado, North Sulawesi, page: 10. Cited from Clive Walker \& Keir Starmer, Ed, 1999, Miscarriages of Justice: A Review of Justice in Error, Blackstone Press Limited, page: 3. According to Black's Law Dictionary, miscarriage of justice is defined as "A grossly unfair outcome in a judicial proceeding, as when a defendant is convicted despite a lack of evidence on an essential element of the crime". It is synonymous with "failure of justice". (Bryan A. Garner, Editor in Chief, 1999, Black's Law Dictionary, Seven Ed., West Group, page 1013). The word "miscarriage" in Indonesian language is defined as "kegagalan (failure) (of justice)" (John M. Echols \& Hassan Shadily, 1995, Kamus Inggris Indonesia, PT. Gramedia, Jakarta: page 382).

8 Otto Cornelis Kaligis, 2008, Ibid, page: 8. Michael Kirby in Otto Cornelis Kaligis describes miscarriage of justice as a separating dark shadow which creates a gap between justice and reality, between the procedure of law in a criminal justice system and the act of criminal law enforcement. ibid, page: 9-10.

9 Otto Cornelis Kaligis, 2008, Ibid, page : 7 
average of 9 years for criminal act of homicide; 371 people who were sentenced to an average of $10-1 / 3$ years for the criminal act of rape; 18 people who passed away in prison after serving an average sentence of 10-1/2 years; 2,357 people who were acquitted; 355 people who were acquitted after "a false confession" was found, out of these 355 people, a total of 156 people in the United States. ${ }^{10}$

One of the concepts considered to be appropriately applied in dealing with various legal issues as described above is the approach of restorative justice principle. ${ }^{11}$ The restorative justice approach in criminal (penal) case settlement is considered as a new method, although most of the patterns being applied have been rooted in the values of local wisdom of primitive people. ${ }^{12}$ The restorative justice principle is an approach which is more focused on creating conditions of harmonization and balanced justice for the victim and the perpetrator of crime. The criminalization oriented mechanism of criminal procedure and justice is shifted to the process of dialogue and mediation with an orientation towards the restoration of justice for victims and reaching an agreement for a more just and balanced criminal case settlement for the victim and the offender concerned.

The restorative justice concept is understood by some parties as a form of nonlitigation or settlement outside the framework of the criminal judiciary system. Although in essence the concept of restorative justice is a criminal law concept and it is different from the concept of alternative Dispute Resolution (ADR) in the settlement of civil cases. Similarly to the concept of diversion adopted in the provisions of Law No. 11 Year 2011 concerning the Juvenile Judiciary system, this is an ADR concept which in fact focuses on children as Perpetrators of crime.

It is different from the criminal judiciary system adopted in the provisions of Law No. 21 Year 2001 concerning special Autonomy for Papua Province, which combines customary judiciary (peradilan adat) system and the positive criminal judiciary system. That is, criminal cases are settled based on the ADR concept in customary judiciary institutions whereby such customary judgment is subsequently brought to the District Court Judge for stipulation. The purpose of such stipulation is to provide legitimacy for judgments made based on the agreement reached in the said customary judiciary system.

The general overview of the phenomena of understanding restorative justice

\footnotetext{
Ibid, page: 7 cited from (http://forejustice.org)

In 1980s, John Braithwaite introduced a punishment system using the restorative justice approach since he was inspired by Maori people in dealing with inappropriate conducts in their society, which emphasizes problem-solving by involving the community and local community leaders to resolve the problem amicably. This conflict-handling method by applying the restorative justice approach applied by the Maori people was adopted in The Children, Young Person and their Families Act as a development made by the Police in the practice of problem settlement amongst the Maori people by involving the offender, the victim, and the community concerned (whanau, hapu and iwi). See Eva Achjani Sulfa, 2009, opcit, page: 22-23. See also Chris Graveson, Police Involvement in Juvenile Crime: Prevention dan Divertion, Juvenile Justice National Seminar Paper on Developing the Concept of Diversion and Restorative Justice, A Cooperation between UNICEF, Mabes Polri and Sentra HAM FHUI, presented in Jakarta on December 11, 2003 p. 2.

13 In John Braithwaite's words: "according to its proponent, restorative justice is not a new invention. Rather, it is a return to traditional pattern of dealing with conflict and crime that had been present in different cultures throughout human history. John Braithwaite, 2002, Restorative Justice and Responsive Regulation, Oxford University Press, p. 1. See also Margarita Zernova, 2007, Restorative Justice, Ideals and Realities, Ashgate Publishing Limited, p. 7. According to its proponent, restorative justice is not a new invention. Rather, it is a return to traditional pattern of dealing with conflict and crime that had been present in different cultures throughout human history.
} 
principle within the National Police of the Republic of Indonesia essentially indicates the existence of an understanding which positions the restorative justice principle outside the criminal judiciary system. Accordingly, the restorative justice principle is considered as a criminal case settlement concept equivalent to the alternative Dispute Resolution (ARD) concept, which functions entirely outside the criminal judiciary system.

Having observed the developments as described in the above stated background, the author became interested in formulating the paper title, namely "Legitimacy of the restorative justice principle in the criminal law enforcement concept" by examining the essence of the restorative justice principle from the perspective of criminal law theories in order to construct a new concept of restorative justice principle within the criminal law enforcement concept. The objective of this research is to understand the essence of the restorative justice principle in criminal law enforcement, in order to construct a restorative justice principle which has legitimacy within the criminal judiciary system, as a new theory in criminal case settlement.

The type of research used in this paper is normative research, reviewing the restorative justice principle from the perspective of the criminal law system, with the aim of constructing a restorative justice concept which is ideal to be applied in criminal law enforcement.

The data being used include secondary data consisting of primary law materials in the form of laws and regulations, tertiary law materials in the form of reference books, opinion of experts, and the outcomes of previous research, as well as tertiary law materials in the form of language dictionaries, scientific law dictionary, and Black's Law Dictionary.

The analysis method applied in this paper starts with the abstraction of primary law materials, secondary law materials and tertiary law materials, leading to an understanding of the essence of the restorative justice principle as well as criminal law theories, analyzing the weaknesses of the restorative justice principle in the criminal law enforcement system in its contemporary meaning and application, followed by systematization and synchronization, and finally, drawing conclusions based on the deductive syllogism reasoning method to construct a new concept of the restorative justice principle within the criminal law enforcement concept.

\section{Current Research and Discussion}

Various countries have developed the concept of Restorative justice as a concept applying a new method for the settlement of criminal matters. The implementation of the restorative concept in such countries has been designed as a new method more commonly applied for the settlement of criminal cases involving children in conflict with the law, as well as misdemeanours, focusing on the reconciliation of victims, offenders, and the community concerned.

The implementation of the restorative justice principle as an approach in settling criminal cases has raised concern among many parties, particularly related to legitimacy, accountability, as well as supervision related aspects in the application of such method. ${ }^{13}$ Kate Warner in Declan Roche warns that problems may potentially

\footnotetext{
${ }^{14}$ grammes. Carolyn Hoyle who conducted comprehensive evaluation of the process of conference scheme conducted by police in implementing the restorative justice principles in Thames valley England, expresses concern about that conference scheme by highlighting the need for more enhanced accountabil-
} 
arise in the conference scheme due to a lack of public scrutiny and accountability by analyzing the restorative justice principle from the often overlooked perspective of young female offenders. ${ }^{14}$ Jennifer Brown in Declan Roche also critiques one form of the restorative justice principle, particularly in mediation between victims and offenders, by arguing that such programmes have numerous procedural deficiencies, including lack of public accountability. ${ }^{15}$

Understanding and the implementation of the restorative justice principle which tends to position the criminal case settlement mechanism by taking it out of the criminal judiciary system framework, is in fact a source of concern to the author, not only due to the program's poor public accountability mechanism, but also related to the concern expressed by OC Kaligis about the "miscarriage of justice" mentioned in his Professorial Inauguration speech on November 8, 2008.

In the author's view, the great number of cases of miscarriage of justice occuring in the criminal judiciary process, including those taking place in developed Countries ${ }^{16}$, is in fact a cause for serious concern, particularly if the process of settling criminal cases is conducted outside the criminal judiciary system. Jennifer Brown views such process as having numerous procedural limitations, including lack of public accountability, while in the opinion of Kate Warner it lacks public supervision and accountability. In addition to the above, in the author's view, the greatest cause for concern is the absence of legitimacy in the decision or output of the criminal cases settlement process taking place outside the criminal judiciary system framework.

In line with the understanding introduced by Howard Zehr, ${ }^{17}$ the restorative justice approach in settling a criminal case must be based on justice and legitimacy as its reinforcement aspect, therefore, it must remain within the criminal punishment framework referred to as "restorative punishment". Such view of Zehr implies the notion that, basically, the restorative justice principle must be applied within the criminal judiciary system, and settlement cannot be reached if it is conducted outside the criminal judiciary system. ${ }^{18}$

According to OC Kaligis ${ }^{19}$, the legitimacy of the criminal judiciary system lies between

ity mechanism and adheres to the semi-public nature of the process and regulatory systematic aspect from the judicial perspective. See Declan Roche, 2003, Accountability of Restorative Justice, Clarendon Studies of Criminology, Oxford University Press, New York, p: 19.

15 Warns that problems may arise in a conferencing scheme that 'lacks public scrutiny and accountability'. Analysing of restorative justice from the often overlooked perspective of young female offenders. Ibid, p: 19.

${ }^{16}$ in her critique of one form of restorative justice-victims-offenders mediation- argues that such programmes have numerous procedural deficiencies, including a lack of public accountability, Ibid, p: 19.

17 The victims of miscarriage of justice in 70 countries consist of: 182 people executed; 498 facing death penalty; 543 subject to lifetime sentence; 1.124 sentenced for criminal act of homicide with the average sentence of 9 years; 371 sentenced for the crimical act of rape with average sentence of 10-1/3 years; 18 people died in in prison after facing average sentence of 10-1/2 years; 2.357 acquitted; 355 acquitted after "a false confession" out of these 355, 156 people were in the United States of America. OC Kaligis, 2008, p. 7-8.

${ }^{18}$ Howard Zehr, 1990, changing Lenses, A New Focus For Crime and Justice, Herald Press, Scottdale PA, p. 209 as cited by Eva Achjani Sulfa, June 2009, Doctoral Dissertation Opcit, p 128.

there are some countries such as: Australia, Canada, Finland, Ghana, Bulgaria, Belgium and Tasmania which translate the restorative justice principles as the concept of mediation conducted outside the criminal justice system, and there are some countries such as England, New Zealand, South Africa, which incorporate the restorative justice principles as part of punishment system, Eva Achjani Sulfa, June 2009, Doctoral Dissertation, Opcit, p. 159.

${ }^{19}$ OC Kaligis, 2008, op cit, p. 13-14. 
two pillars, namely: effectiveness and fairness of the criminal judiciary system. Effectiveness is assessed based on the ability and precision or accuracy in detecting, conducting investigation, probe, inquiry, prosecution, examination in the hearings, up to the point of imposing the appropriate punishment on the defendant who has been proved guilty of committing a criminal act, up to the level of enforcement of the criminal punishment. At the same time, fairness is assessed based on carefulness, meticulousness, as well as efforts made by the state in fulfilling obligations related to the criminal offender's rights in the judicial process with due observance of the legal principles and the provisions of standard procedures set forth in laws and regulations. ${ }^{20}$

Based on Aertsen's view on New informalism, Eva in her dissertation also expresses the view that Zehr's viewpoint brings an in quasi or not pure restorative justice, as the view appears to set aside the voluntarism aspect as the characteristics of restorative justice approach in settling criminal cases.

Roach in Eva $^{21}$ questions the implementation of restorative justice principle in serious cases. Bazemore ${ }^{22}$ is of the opinion that the restorative justice principle may be implemented in all types of criminal acts, as the extent of a criminal act can not serve as the parameter for determining the appropriate method for settlement. In the author's view, apart from the lack of parameter for implementing the restorative justice principle, basically, the focus of settlement should be on the fulfillment of the victim's sense of justice, rather than on the nature of the punishment system itself. In fact, determining the appropriate punishment will vary for the victims in each case, depending on the emotional value of the victims concerned.

In the author's opinion, the restorative justice principle can only be applied in the criminal judiciary system, and not outside the system. Such opinion is in line with Howard Zehr and Ahmad Ali's view which draws a clear distinction between the implementation of the restorative justice principle as a method for settling criminal cases by implementing the concept of Alternative Dispute Resolution (ADR) as out-ofcourt settlement, namely a civil case settlement method. The author's understanding has been inspired by the view expressed by OC Kaligis, as stated in his Professorial inauguration speech namely that: ${ }^{23}$

“............. sistem peradilan pidana Indonesia ke depan perlu dikembangkan menjadi suatu sistem peradilan pidana restoratif yang tujuannya tidak hanya mengurangi kejahatan dan mengurangi dampak buruk dari kejahatan, tetapi juga dapat menghilangkan kemungkinan terjadinya miscarriage ofjustice. Di samping itu, sistem peradilan pidana restoratif yang menekankan pemulihan kebutuhan emosional dan relasional dari korban, pelaku, dan masyarakat umumnya merupakan kunci untuk mencapai dan mempertahankan "a civilized and decent society."

[Unofficial translation: “..... in the future, the Indonesian criminal judiciary system needs to be developed into a restorative criminal judiciary system, the purpose of which is not only to reduce crime and reduce the negative impacts of crime, but also eliminating the potential miscarriage of justice. In addition to the foregoing, restorative criminal judiciary system which emphasizes the restoration of

$20 \quad$ Ibid, p. 13-14.

21 Raymond R. Corrado et. al, Multi-Problem Violenct Youth; A Challenge for the Restorative Justice Paradigm in Elmar G.M. Weitekamp and Hans-Jurgen Kerner, 2003, Restorative Justice Context, Wulan Pubhlising, Devon, p. 2 in Eva Achjani Sulfa, July 2009, op cit, p. 27.

$22 \quad$ Ibid, p. 27.

23 OC Kaligis, 2008, opcit, p. 13-14. 
the emotional and relational needs of victims, offenders, and the community at large is the key to achieving and maintaining "a civilized and decent society."]

Such understanding has laid the basis for the author in constructing the restorative justice principle in the concept of criminal law enforcement, with the understanding that the implementation of the restorative justice principle must be constructed within the criminal judiciary system framework as legitimatization of its reinforcement, which OC Kaligis refers to as "restorative criminal judiciary system", hence it is not solely intended to restore relations between the victims, the offenders, and the community concerned, but more than that, the purpose of justice by avoiding miscarriage of justice can be achieved.

\section{III.The Restorative Justice Principle}

The word Restorative justice originates from two English words, namely: "restoration" meaning: repair; recovery; or reconstruction, and "justice" meaning: equity. "Restorative" means: (noun) curing/strengthening/refreshing medicine; (adjective) something which strengthens, cures, or refreshes. ${ }^{24}$ Therefore, according to its etimology the definition of restorative justice is 'curing' justice or 'recovering' justice.

There are many terms used to describe the restorative justice movement, among other things: "communitarian justice", "positive justice", "relational justice", "reparative justice", "community justice", et cetera. ${ }^{25}$

Restorative justice, according to a UN entity, UNODC in the Handbook of Restoratice justice: "Restorative justice is an approach to problem solving that, in its various forms, involves the victim, the offender, their social networks, justice agencies and the community."

The definition of Restorative Justice according to the Restorative Justice consortium 2006, is: ${ }^{26}$

"Restorative justice works to resolve conflict and repair harm. It encourages those who have caused harm to acknowledge the impact of what have done and gives them an opportunity to make reparation. It offers those who have suffered harm the opportunity to have their harm or loss acknowledged and amends made."

Furthermore, restorative justice according to Tony F. Marshall is: "a process whereby parties with a stake in a specific offence collectively resolve how to deal with the aftermath of the offence and its implications for the future." ${ }^{27}$

\footnotetext{
${ }^{24}$ John M Echol and Harun Shadily, 2000, Kamus Inggris Indonesia, PT. Gramedia, Jakarta, p. 339 and 482.

25 United Nations, 2006, Handbook on Restorative Justice Programmes, Criminal Justice Handbook series, United Nations Office on Drugs and Crime (UNODC), Vienna Austria, p: 6. It is explained that "Restorative justice is a way of responding to criminal behaviour by balancing the needs of the community, the victims and the offenders

${ }^{26}$ See Mariam Liebmann, 2007, Restorative Justice: How it Works, Jessica Kingsley Publishers, London: p. 25. (Restorative justice works to resolve conflict and correct misconduct, to encourage those who have caused losses to acknowledge the impact of what they have done, to provide them the opportunity to make improvement, to offer those who have suffered losses to have the opportunity to be given compensation or to be acknowledged of the loss and to redempt the misconduct).

${ }^{27}$ Marshall, Tony F. 1999. Retorative Justice an Overview. London: Home Office, Information \& Publications Group, p. 5. Restorative justice is a "process which involves all parties who have interests in certain matters of violation to come together to settle the problem collectively, how to respond and resolve the
} 


\section{Howard Zehr in his book, "The Little Book of Restorative Justice" defines Restorative Justice as: ${ }^{28}$}

"a process to involve to the extent possible, these who have a stake in a specific offence and to collectively identify and address harms, needs, and obligations, in order to heal and put things as right as possible."

Further, according to Sharpe ${ }^{29}$ restorative justice has fundamental characteristics with various values referred to as participation, democracy, responsibility, restoration, security, recovery, and reintegration.

John Braitwaith defines the concept of restorative justice as: ${ }^{30}$

"Restorative justice is a procces brings together all stakeholders in effected by some harm. That has been done.... These stakeholders meet in a circle to discuss how they have been affected by the harm and come to some agreement as to what should be done to right any wrongs suffered... restorative justice is about healings (restorative) than hurting."

Burt Galaway and Joe Hudson offer the definition of the concept of Restorative justice: ${ }^{31}$

consequences of such violation and the implication for the future." See also James Dignan, 2005, opcit, p. 3. See also John Braithwaite, 2002, Restorative Justice and Responsive Regulation. Ofxord: Oxford University Press, p. 10. Restorative justice (sometimes is also referred to as "reparative justice") is fundamentally an approach to justice which focuses on the needs of victims, offenders, and the community involved, instead of satisfying the abstract legal principles or punishing the offfenders. Victims play active roles during the process, while offenders are encouraged to take responsibility for their actions, "to repair the harm they cause by apologizing, restoring the condition, or performing community service".

${ }^{28}$ See Howard Zehr, 2002, The Little Book of Restorative Justice, Good Books Intercourse, United State Of America, p. 37. There are three main ideas which support restorative justice, according to Howard Zehr, namely: First, the understanding that the victims and the community who own both the victims and the offenders have been affected by the action of the offenders, and apart from it, restoration is required. Secondy, the offender's obligation is to redempt his/her misconduct to both the victims and the community involved. Thirdly, and the most important process of restorative justice is the concept of recovery. This step has two parts: the recovery of the victims and the fulfilment of the offenders' personal needs. Both parties are equally important in the recovery process to avoid residivism and for the victims, to regain their sense of security

${ }^{29}$ Yayasan Pemantau Hak Anak, Children's Human Rights Foundation, Anak yang Berhadapan dengan Hukum dalam Perspektif Hukum Hak Asasi Manusia Internasional, Website Internet : www.ypha.or.id/.../ Anak-yang-Berhadapan-dengan-Hukum-dalam-Perspektif-Hukum-HAM-Internasional3.pdf, accessed on October 17, 2013, p. 5, p. 8

${ }^{30}$ See John Braitwaite, 1990, Crime Shame and Reintegration, Chambridge University Press, Chambridge. Cited by Eva Achjani Sulfa, June 2009, opcit, p. 50-51. Restorative justice is the process of bringing together all stakeholders involved in the issue. What have been done .... by the stakeholders is meeting in a circle to discuss how they have been affected by the danger and to make some agreements concerning what to be done in the future and each errors suffered. That restorative justice is about restoring rather than hurting.

${ }^{31}$ Burt Galaway and Joe Hudson, 1990, Criminal Justice, Restitution and Reconciliation, Criminal Justice Press, Mosey, New York, p. 2. Also cited by Eva Achjani Sulfa, June 2009, ibid, p. 51. That the fundamental element of the definition of restorative justice is: firstly, a crime is viewed as a conflict among individuals which results in the loss to the victims, the offenders, and the community; secondly, the purpose of the criminal justice process must be to create peace within the community through the reconcilation of the parties and to repair the damage caused by a dispute; thirdly, the criminal justice process must facilitate active participation of the parties, the victims, the offenders, and the community in the context of finding 
"A definition of restorative justice includes the following fundamental element : first, crime is viewed primarily as a conflict between individuals this results injuries to victims, communities, and the offenders themselves; second, the aim of the criminal judiciary process should be to create peace in communities by reconciliation the parties and the repairing the injuries caused by dispute; thirds, the criminal judiciary process should pacilitate active participation by victims, offenders and their communities in order to find solutions to the conflict."

Marian Liebmann defines restorative justice simply as a legal system whose "objective is to restore the welfare of the victims, offenders, and the community damaged by a crime, and to avoid further violation or criminal act." 32

There is a common view of Restorative justice as a philosophy, a process, an idea, a theory and an intervention. ${ }^{33}$ Restorative justice is a justice system which emphasizes repair of any harm caused by or related to a criminal act. Restorative justice is implemented through a cooperative process involving all parties (stakeholders). ${ }^{34}$

Muladi states that in restorative justice, the victims' dignity is taken into account. Offenders must take responsibility and they must be reintegrated into the community. Offenders and victims are in an equal position and mutually need each other, therefore, they must be reconciled. ${ }^{35}$

According to Eva Ahjani Sulfa, restorative justice is a concept of thought which responds to the development of criminal judiciary system by emphasizing the need to involve the victims and the community that appear to have been unrecognized under the mechanism applied in the existing criminal judiciary system. ${ }^{36}$

The key word for restorative justice is "empowerment", the word empowerment is at the heart of restorative ideology, therefore, the success of the implementation of restorative justice is determined by such empowerment. ${ }^{37}$

the solution to the conflict.

32 See Marian Liebmann, 2007, opcit, p. 25. Liebmann also provides the formulation for the basic restorative justice principle as follows: 1 . Prioritizing support to and recovery of the victims; 2 . The offenders shall be responsible for their actions; 3. Dialogue between the victims and the offenders to reach an understanding; 4 . There is an effort to position the loss incurred correctly; 5 . The offenders must be aware of how to avoid crime in the future; 6 . The community must also assist in integrating both parties, the victims and the offenders. See Manshur Zikri, June 1, 2011, Restorative Justice as A Case Settlement Mechanism which Prioritizes the Interest of Women as Victims of Sexual Abuse, Website Internet http://manshurzikri.wordpress.com/2011/06/01/restorative-justice-sebagai-mekanisme-penyelesaian-perkara-yang-mengedepankan-kepentingan-perempuan-sebagai-korban-kekerasan-seksual/, accessed on September 25, 2011.

${ }^{33}$ Kuat Puji Prayitno, September 3, 2012, Restorative Justice Untuk Peradilan Di Indonesia (Perspektif Yuridis Filosofis Dalam Penegakan Hukum In Concreto), Journal of Law Dynamics Vol. 12 No. 3, September 2012, p. 409. Kuat Puji Prayitno cited the opinions of the experts, among them, John Braithwaite, Umbreit and Cary, Richardson, Umbreit and Coates, Graef, and Du Pont. See Darrell Fox, 2009, "Social Welfare and Restorative Justice”, Journal Kriminologija Socijalna Integracija Year 2009 Vol 17 Issue 1 Pagesrecord No. 55-68, Metropolitan University Department of Applied Social Sciences, London, p. 56.

${ }^{34}$ Ibid. "Restorative justice is a theory of justice that emphasizes repairing the harm caused or revealed by criminal beha-viour. It is best accomplished through cooperative processes that include all stakeholders."

${ }^{35}$ Anonimous, June 16, 2012, Pengertian dan tujuan Restorative Justice, website internet : http://luqmanpinturicchio.blogspot.com/2012/06/restorative-justice-bagian-ii.html, accessed on October 21, 2013.

${ }^{36}$ Eva Achjani Zulfa, 2010, Pergeseran Paradigma Pemidanaan, Lubuk Agung, Bandung, p. 65.

37 C. Barton, Empowerment and Retribution ini Criminal Justice, Dalam H. Strang, J. Braitwaite (eds), 2011, "Restorative Justice: Philosophy to Practice". Journal TEMIDA Mart 2011. Aldershot: Ashgate/Dartmouth, p. 55-76. 
The definition of restorative justice above may be identified in several dimensions, among others: restoration is the restoration of relationship between the victims and the offenders; restoration or recovery may also be understood as the recovery of the victims' lossess or damages resulting from the offenders' action; while the dimension of justice is aimed at individual justice, namely justice for the victim.

Referring to the above description, restorative justice is one way of addressing the issue of criminal act behaviour by balancing the needs of the community, the victims, and the offenders. The community plays an important part in the process of restrorative justice as (i) a criminal act may originate from relationship patterns and social conditions in the community concerned; and (ii) in some respects, the prevention of criminal act is also the responsibility of the community (together with the central and local governments in developing social policy) to improve conditions which may be the potential source of criminal acts.

\section{The Restorative justice Principle in criminal law}

From the author's viewpoint, the restorative justice principle in its contemporary meaning, particularly according to the understanding which positions it as a method for resolving disputes outside the criminal judiciary system, has certain shortcomings, among other things as follows:

a. The relevant law enforcement system is exclusively based on confession, rather than scientific methods.

b. Not all victims of crime are prepared to forgive, reconcile and resolve their cases through mediation.

c. Not all offenders are prepared to admit their mistakes, or to negotiate, or a paid actor may claim as perpetrator of the crime, thus resulting in the punishment of the innocent (error in persona).

d. Groups in society have different interests in a variety of cases, which may in fact pose a threat to the disputing parties.

e. There is no uniformity of sentence (sanction), which can be considered unfair to the poor.

f. Different points of view regarding the value of good and evil deeds are have cost their significance, any act can be evaluated based on material considerations.

g. It can be potentially exploited by certain parties for their personal gains, or it can even become a source of livelihood.

h. There is no unification in the criminal judiciary process, as the mechanism varies from region to region.

The essence of the restorative justice concept is actually respect for human dignity. Humans are individual and social beings who are not free from mistakes or faults. The problem is that the persons authorized or allowed to impose penalties upon other people who are considered to have committed a crime or violate the rules of law are not necessarily better than the convicts themselves. In fact, it is debatable whether the underlying law itself has the integrity of justice. In the philosophy of divinity, it is God who is the most just, the most perfect, the most powerful, and the most enduring. Therefore, only God is the most rightful to pass down judgment. At the same time, by 
their nature humans should be able to forgive, correct each other, and protect each other. It is more beneficial to the aggrieved victims if their loss is replaced, cured, or restored into its initial state. As for the offenders, they are given the opportunity to realize and correct the mistakes they have made, and restore the good relationship between the victim and the offender.

When deciding whether a person may be held liable for a crime, one must consider the linkage between thought, feeling, and action as a crucial element in determining the mistake and make legal decisions concerning such mistake. ${ }^{38}$ This assumption actually confirms 2 (two) key criteria in demanding legal liability, i.e. mens rea (guilty of mind) and actus reus (guilty act). The first criterion, mens rea, states that the subject is alleged to have committed a crime and therefore ought to be held legally liable if it knows and understands its actions. In other words, the subject has the proper mental capacity to assume legal liability. Knowledge and understanding are insufficient for establishing that a person has committed a criminal act, it must be proven that the subject has committed or actually did commit the crime it is accused of (actus reus). The second criterion, actus reus, is important because it is the most obvious evidence that the suspect does not only understand, but he/she also has the ability to perform the alleged actions.

The phenomenon of criminal case settlement in Indonesia as described by Eva Achjani Sulfa in her dissertation illustrates that the paradigm offered by the restorative justice concept in Indonesia is not an entirely new concept in practice. Non-adversarial dispute resolution practices outside the criminal justice process have been applied by the community as a reflection of the institution of deliberative consensus (musyawarah mufakat) which in its turn reflects the philosophy of the Indonesian nation. Reality has shown that conflict resolution in communities of the Indonesian nation does not always end up in Court even though it is a violation of penal laws and regulations. Dispute settlement through such deliberative institution is conducted with or without the involvement of authorized officials. ${ }^{39}$

\section{Construction of the Restorative Justice Principle in the Criminal Judiciary System}

Friedman ${ }^{40}$ states that law cannot be discussed by viewing it from its structural and substantial aspects alone; rather, its cultural aspect must also be taken into account. Accordingly, the construction of the restorative justice concept under the criminal judiciary system should be viewed from the perspective of the legal system which, according to Friedman, consists of the abovementioned three elements, namely, its legal substance, structure and legal culture.

The inspiration to construct the restorative justice principle within criminal law enforcement, especially in the context of the criminal judiciary system discussed herein, is different from various contemporary meanings assigned to the restorative justice principle, since the author considers that the restorative justice principle must be constructed in the context of the criminal judiciary system. Howar Zehr states that not all victims agree to have their cases settled outside the court system. On the

\footnotetext{
${ }^{38}$ Andre Ata Ujan, 2009, Filsafat Hukum: Membangun Hukum, Membela Keadilan, Kanisius Publisher, Yogyakarta dalam Yayasan Pemantau Hak Anak, Children's Human Rights Foundation, Anak yang Berhadapan dengan Hukum dalam Perspektif Hukum Hak Asasi Manusia Internasional, p. 5

39 Eva Achjani Sulfa, 2009, Opcit, p. 3

${ }^{40}$ Howard Zehr, 2002, opcit, p. 6.
} 
contrary, the victims feel that they do not have the liberty to determine a settlement model, and are forced to enter into a conference between the parties concerned, as a result of which the agreement between such parties does not necessarily reflect justice for the victims or the suspects; rather, it is a deal which must be accepted as a mutual agreement for the common interest. ${ }^{41}$

The basis of the author's understanding is that the implementation of the restorative justice principle is not aimed at fulfilling the aspects of justice and utility only, bearing in mind that the aspect of legal certainty is also essential to accomplishing the purpose of criminal law itself. In order to determine the status of Offender (suspect) and victim, and to decide which community will be involved in the mediation (conference) process to solve the problem is not an easy task, it takes an inquiry process and scientific investigation in order to make them work.

Furthermore, a criminal case has to be reconstructed first in order to determine the principal case or position of the case, so that it can be clearly identified who is responsible as the suspect, who has been harmed as the victim, as well as the type of losses and the form of community involvement in such a case. The case is reconstructed using deductive reasoning aimed at reaching a conclusion about the offender and the type of responsibility that it should bear, the victim and the type of proportional losses it has suffered, and the community which will be at a disadvantage and the parties that are going to be involved to represent such community.

Such reconstruction of criminal events is conducted by applying scientific crime investigation methods in the pre-adjudication stage. By doing so, violation of human rights may be avoided, and the reconstruction is expected to gravitate towards the fulfillment of the sense of justice and legal certainty for all parties involved. There is a need for the investigation process in order to determine the position of the case reported by the victim, so that it is clear whether or not the case concerned is a criminal case so that the appropriate forum to handle a mediation or conference for all parties who wish to be mediated can be established.

The subsequent stage is the investigation process following the inquiry process aimed at shedding light on the criminal act, and based on evidence or facts obtained from the investigation results, the case can be positioned to determine the offender, the victim, the harm suffered, and the public interest in the case concerned. The process of conference (mediation) between the victim, the offender and the community can be implemented not only based on recommendation from both victim and offender as the disputing parties, the position of the case should also be proved scientifically; who is the offender; who is the victim, the extent of the relative harm; the form of the relative liability; and the parties entitled to represent community members in such conference or mediation, including mediators who already possess special skills as certified mediators.

Such conference (mediation) may be conducted in the pre-adjudication stage (inquiry, investigation, indictment at the public prosecutor's office), adjudication stage (examination in court), as well as post-adjudication stage (following the court's judgment, while serving time in a correctional Institution, or after completing a sentence).

Described below is the Construction of the ideal restorative justice principle in the

${ }^{41}$ Friedman,1977, Law and Society, New Jersey : Prentice-Hall, pg. 7 - 9. Friedman's theory which proposes that there are three elements of the legal system namely, substance, structure, and culture. 
criminal judiciary system:

Figure: The construction of the restorative justice Principle in criminal law enforcement (criminal judiciary system).

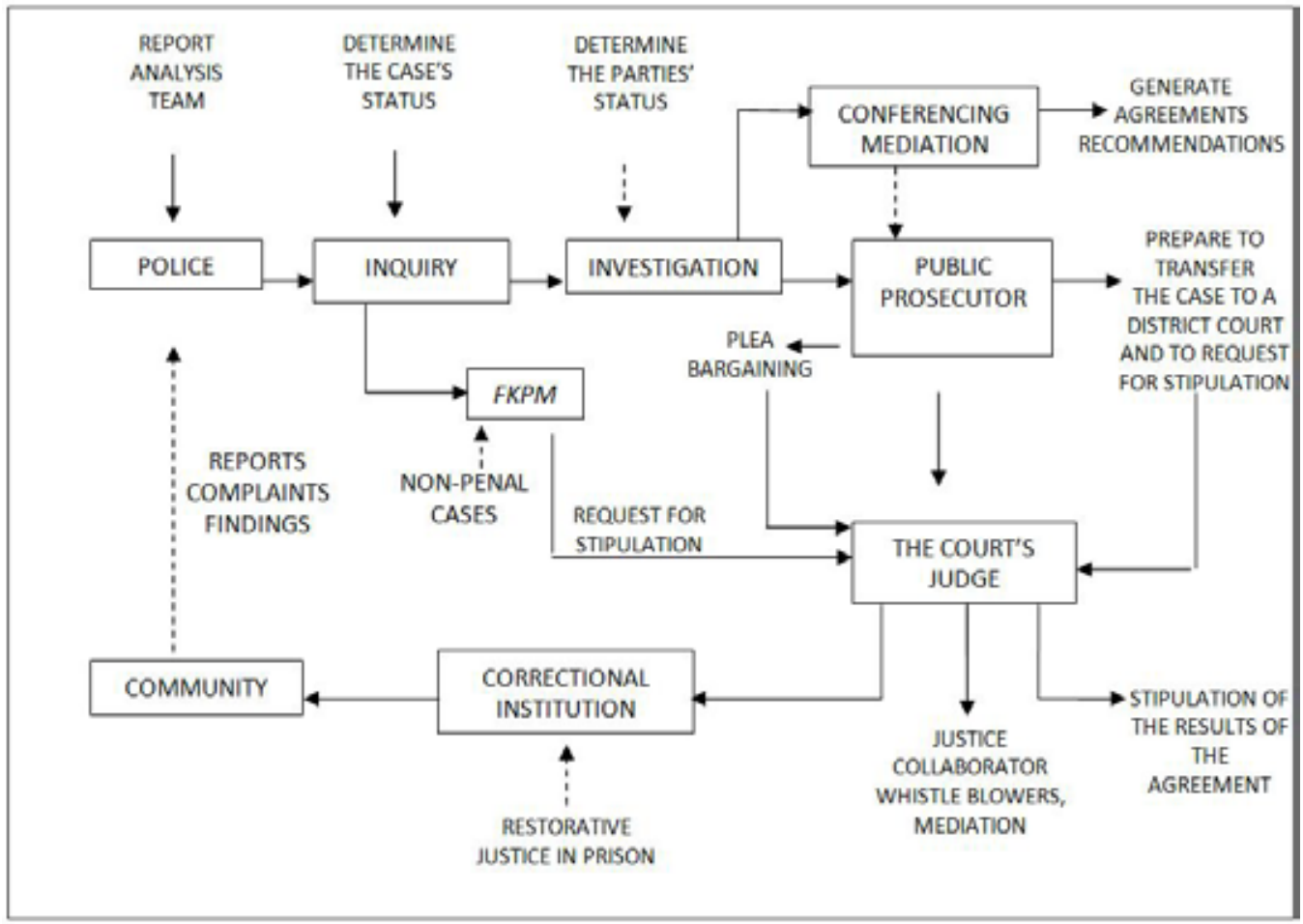

\section{Explanation on Figure:}

a. The public file a report/complain about any problems they face to the Police, or a police officer discovers an incident directly in the field.

b. The report/complaint or the Police officer's finding will then be analyzed to determine the type of case reported/complained about or discovered.

c. The case is submitted to the inquiry Team in order to investigate whether or not the incident is a criminal offense.

d. If the case is not a criminal offense (non-penal), the Informant/complainant will be provided with an option to file a lawsuit directly in accordance with its judicial competence, or submit the case to the FKPM (Community Policing Communication Forum ${ }^{\text {घ }}$ to be mediated and deliberated in order to reach a peaceful settlement.

e. If the case is a criminal offense, it will be transferred to the Investigator in order to gather evidence from the facts of the crime, and to make inferences based on the evidence concerning:

1) Details of the case (position of the case). 
2) The responsible offender (suspect) and the scope of their responsibility.

3) The rightful victim and their proportionate losses.

4) The other parties affected by the incident, or those entitled to be involved in the mediation.

f. If during a criminal investigation, the victim or the parties concerned wish to go for mediation and amicable settlement, the investigator appoints a certified Special Police Mediator to conduct mediation between such parties.

g. The resulting agreement between the parties concerned is set out in a case file, and then submitted to the Public Prosecutor's office.

h. The Public Prosecutor's office: The resulting agreement between the parties concerned in a mediation process during the investigation stage is transferred to the Court to request a stipulation from the court judge, while for a case in which no agreement is reached during the investigation stage, the prosecutor may offer a plea bargain to the offender and the victim.

i. The court judge: the transferred case resulting from the mediation process conducted during the investigation stage and or plea bargaining offered at the prosecutorial level is decided upon and stipulated in accordance with the agreement, while in cases where no agreement is reached, the judge may use the assessment of justice collaborators and whistle blowers, the mediation process or decisions based on positive law. j. Correctional Institutions: convicts serving their sentences are still given the opportunity to conduct mediation in prison, with a consequence on sentence reduction.

k. After an offender completes his/her sentence, it is still possible to conduct mediation in order to discuss the subsequent process of civil prosecution, as well as in the context of reconciliation program, reintegration, resocialization and rehabilitation of relationship between the victims, the offenders and the community.

\section{Conclusion}

In conclusion, this paper highlights the following:

The restorative justice principle, both at the levels of conceptualization and implementation nowadays, is more commonly understood as an alternative method of dispute resolution generally positioned outside the criminal judiciary system which can only be applied to juvenile cases and minor offences, thus it is not yet accommodated in the formal and material provisions of criminal law. Basically, the restorative justice principle in criminal law enforcement can be applied to all types of criminal acts and at all stages of the criminal judiciary system. Whereas for the purpose of providing legitimacy to the implementation of the restorative justice principle there is a need for intervention by the criminal judiciary system, particularly in view of decisions which have permanent and binding legal force.

The restorative justice concept is actually another form of respect for human dignity. The essence of justice in the restorative justice concept is to reflect justice as a form of balance in human life, thus viewing the offender's deviant behaviour as a behavior that disrupts such balance. Accordingly, the model for case settlement should be aimed at attempting restoring the balance, which is not adequately done by simply placing the burden of liability on the offenders and their conscience to confess their 
mistake, apologize, and restore the damages and harm suffered by the victims into its initial state, but it also requires scientific proving through the mechanism of scientific procedures, so that the application of the restorative justice concept in criminal law enforcement remains within the domain of the criminal judiciary system.

The implementation of the restorative justice principle needs to be constructed within the concept of criminal law enforcement which is accommodated under the Draft of Criminal Code $(R K U H P)$ and the draft Code of Criminal Procedure (RKUHAP) as a legal umbrella, by clearly defining the role of each subsystem element of the criminal judiciary system, both in terms of formal and material substance of law, the legal structure starting from the inquirers, investigators, public prosecutors, court Judges, correctional Institutions, as well as the community's legal culture which supports the implementation of the restorative justice concept in the criminal judiciary system, particularly with regards to community participation empowerment, the process of reconciliation, reintegration and resocialization following the implementation of the restorative justice concept

\section{Bibliography}

Achmad Ali, 2008, Menguak Tabir Hukum, (Unveiling the Law), Ghalia Indonesia, Bogor.

Andre Ata Ujan, 2009, Filsafat Hukum: Membangun Hukum, Membela Keadilan, (Philosophy of Law: Developing the Law, Defending Justice), Penerbit Kanisius, Yogyakarta.

Anonymous, 16 June 2012, Pengertian dan tujuan Restorative Justice, (The Concept and Purpose of Restorative Justice), internet website: http://luqmanpinturicchio. blogspot.com/2012/06/restorative-justice-bagian-ii.html, accessed on 21 October 2013.

Bryan A. Garner, Editor in Chief, 1999, Black's Law Dictionary, Seven Ed., West Group. Burt Galaway and Joe Hudson, 1990, Criminal Justice, Restitution and Reconciliation, Criminal Justice Press, Mosey, New York.

Chris Graveson, 2003, Police Involvement in Juvenile Crimes: Prevention dan Divertion, A Paper from the National Seminar on Juvenile Justice in Developing the Concepts of Divertion and Restorative Justice, A Collaboration between UNICEF, Headquarters of the Indonesian National Police (Mabes Polri) and FHUI Centre of Human Rights, presented in Jakarta on 11 December 2003.

Clive Walker \& Keir Starmer, Ed, 1999, Miscarriages of Justice: A Review of Justice in Error, Blackstone Press Limited.

Darrell Fox, 2009, "Social Welfare and Restorative Justice", Journal Kriminologija Socijalna Integracija Year 2009 Vol. 17 Issue 1 Pagesrecord No. 55-68, Metropolitan University Department of Applied Social Sciences, London.

Declan Roche, 2003, Accountability of Restorative Justice, Clarendon Studies of Criminology, Oxford University Press, New York.

Elmar G.M. Weitekamp and Hans-Jurgen Kerner, 2003, Restorative Justice Context, Wulan Publishing, Devon.

Eva Achjani Sulfa, June 2009, Keadilan Restoratif Di Indonesia (Studi tentang Kemungkinan Penerapan Pendekatan Keadilan Restoratif Dalam Praktik Penegakan Hukum Pidana), (Restorative Justice in Indonesia (A Study of the Possible Application of the Restorative Justice Approach in Criminal Law 
Enforcement Practices), Doctoral Dissertation in Law from the Faculty of Law of Universitas Indonesia.

2010, Pergeseran Paradigma Pemidanaan, (A Shift of Paradigm in Criminalization), Lubuk Agung, Bandung.

Friedman,1977, Law and Society, New Jersey: Prentice-Hall.

Howard Zehr, 1990, Changing Lenses, A New Focus for Crime and Justice, Herald Press, Scottsdale PA.

2002, The Little Book of Restorative Justice, Good Books Intercourse, United States of America.

H. Strang, J. Braithwaite (eds), 2011, "Restorative Justice: Philosophy to Practice". Journal TEMIDA March 2011. Aldershot: Ashgate/ Dartmouth.

James Dignan, 2005, opcit, p. 3. See also John Braithwaite, 2002, Restorative Justice and Responsive Regulation. Oxford: Oxford University Press.

Jecky Tengens, Tuesday, 19 July 2011, Pendekatan Restorative Justice dalam Sistem Pidana Indonesia, Internet Website: http://hukumonline.com/berita/ baca/ lt4e25360a422c2/ pendekatan-restorative-justice-dalam-sistem-pidanaindonesia, accessed on 25 September 2011.

John Braithwaite, 1990, Crime Shame and Reintegration, Cambridge University Press, Cambridge. Press.

2002, Restorative Justice and Responsive Regulation, Oxford University

John M. Echols \& Hassan Shadily, 1995, English-Indonesian Dictionary, PT. Gramedia, Jakarta.

2000, English-Indonesian Dictionary, PT. Gramedia, Jakarta.

Kuat Puji Prayitno, 3 September 2012, Restorative Justice untuk Peradilan di Indonesia (Perspektif Yuridis Filosofis dalam Penegakan Hukum In Concreto), Jurnal Dinamika Hukum Vol. 12 No. 3 September 2012.

Manshur Zikri, 1 June 2011, Restorative Justice Sebagai Mekanisme Penyelesaian Perkara yang Mengedepankan Kepentingan Perempuan sebagai Korban Kekerasan Seksual, Internet Website: http://manshurzikri.wordpress. com/2011/06/01/restorative-justice-sebagai-mekanisme-penyelesaianperkara-yang-mengedepankan-kepentingan-perempuan-sebagai-korbankekerasan-seksual/, accessed on 25 September 2011.

Margarita Zernova, 2007, Restorative Justice, Ideals and Realities, Ashgate Publishing Limited.

Mariam Liebmann, 2007, Restorative Justice: How It Works, Jessica Kingsley Publishers, London.

Marshall, Tony F. 1999. Restorative Justice an Overview. London: Home Office, Information \& Publications Group.

Otto Cornelis Kaligis, 2008, Miscarriage of Justice dalam Sistem Peradilan Pidana: Perlunya Pendekatan Keadilan Restoratif, (Miscarriage of Justice in the Criminal Judiciary System: The Need for Restorative Justice Approach), Professorial Inaugural Lecture, Universitas Negeri Manado, North Sulawesi.

Soesilo, R., 1995, Kitab Undang-Undang Hukum Pidana (KUHP) serta KomentarKomentarnya Lengkap Pasal demi Pasal, (The Criminal Code and Comprehensive Commentary on an Article By Article Basis), Print 1, Politeia: Bogor.

Saladin Ayyubi/Global/fit, Thursday, 19 November 2009, Hakim Menitikkan Air Mata Baca Putusan Nenek Pencuri 3 Biji Buah Coklat, (Judge Tears Up While Reading Out Sentence on Grandmother Who Had Stolen 3 Cacao Beans), NewsNusantara, Internet Website: http://news.okezone.com/read/2009/11/ 
20/340/277729/340/hakim-menitikkan-air-mata-baca-putusan-nenekpencuri-3-biji-buah-coklat, accessed on 25 September 2011.

United Nations, 2006, Handbook on Restorative Justice Programmes, Criminal Justice Handbook series, United Nations Office on Drugs and Crime (UNODC), Vienna, Austria.

Yayasan Pemantau Hak Anak, Children's Human Rights Foundation, Anak yang Berhadapan dengan Hukum dalam Perspektif Hukum Hak Asasi Manusia Internasional, (Children Facing the Law, from the International Human Righst Perspective). Internet Website: www.ypha.or.id/.../Anak-yang-Berhadapandengan-Hukum-dalam-Perspektif-Hukum-HAM-Internasional3.pdf, accessed on 17 October 2013.

Law No. 1 of the Republic of Indonesia Year 1946 on the Regulations on Criminal Law (Official Gazette of the Republic of Indonesia II Number 9) jo Law No. 73 Year 1958 on the Applicability of Law Number 1 Year 1946 concerning the Regulations on Criminal Law to the Entire Territory of the Republic of Indonesia and the Amendment to the Criminal Code (State Gazette of the Republic of Indonesia Year 1958 Number 127, Supplement to State Gazette of the Republic of Indonesia Number 1660) which have been amended and supplemented several times, most recently with Law Number 27 Year 1999 concerning the Amendment to Criminal Code Relating to Crimes against State Security (State Gazette of the Republic of Indonesia Year 1999 Number 74, Supplement to State Gazette of the Republic of Indonesia Number 3850).

Law No. 8 Year 1981 on the Code of Criminal Procedure (State Gazette of the Republic of Indonesia Year 1981 Number 76, Supplement to State Gazette Number 3209).

Law No. 21 Year 2001 on Special Autonomy of the Papua Province (State Gazette of the Republic of Indonesia Year 2001 Number 135, Supplement to State Gazette of the Republic of Indonesia Number 4151).

Law No. 11 Year 2012 on Children Criminal Justice System (State Gazette of the Republic of Indonesia Year 2012 Number 153, Supplement to State Gazette of the Republic of Indonesia Number 5332). 